\title{
Do Analysts Cater to Investor Information Demand?
}

\author{
Miran Hossain \\ Cameron School of Business \\ University of North Carolina - Wilmington \\ Benjamin A. Jansen ${ }^{1}$ \\ Jones College of Business \\ Middle Tennessee State University \\ Jon Taylor \\ College of Business \\ Florida Atlantic University
}

This draft: 03/20/2020

\begin{abstract}
We extend analyst following literature by investigating whether analysts cater coverage towards investor information demand. Results suggest analyst following increases during the months in which a firm's stock ticker experiences abnormal information demand from investors, while the association is marginally negative in the following month. However, the magnitude of the contemporaneous positive association is greater than the magnitude of the proceeding negative association. This implies that analysts respond to information demand shocks, but partially revert their coverage after the abnormal information demand subsides. Furthermore, our results suggest that analysts cater their coverage more towards institutional investors, relative to retail investors.

JEL: G14; G23; G24; G29

Keywords: Analyst Coverage; Information Demand; Institutional Investor; Retail Investor \footnotetext{
Association, 2018 Southwestern Finance Association, seminar participants at Middle Tennessee State University, and the Florida Atlantic University brown bag.
}

${ }^{1}$ Contact:Benjamin.Jansen@mtsu.edu. We would like to thank conference participants at the 2019 Southern Finance
\end{abstract}




\section{Introduction}

Financial analysts are an integral component of market information and there is much research investigating the effect of financial analyst coverage as well as what may motivate analyst coverage. However, Beyer et al. (2010) note that while the effects of analyst coverage have been well researched ${ }^{2}$, there has been relatively little research investigating the demand for analyst coverage and how analysts respond to this demand. Additionally, Brown et al. (2015) provide survey evidence suggesting analysts follow investor demand for information; the survey reports that hedge funds are the most important clients of analysts, followed by mutual funds and retail investors. How analysts respond to investor demand for information is important to investigate because although prior studies have focused on analysts' motivation for covering a firm, few studies have investigated how analyst coverage responds to investor interest. Additionally, we investigate which demand component, the institutional or retail investor, has a stronger effect on analyst coverage.

We expand the literature by empirically testing whether analysts respond to investor demand for information. We model analyst coverage as a function of institutional investors' demand (IID), proxied by news readership on Bloomberg terminals. We also test whether analysts cater to retail investors' demand (RID) by estimating analyst following as a function of

\footnotetext{
${ }^{2}$ Some factors which prior literature has researched in being related to analysts following a firm include: firm characteristics ((Bhushan (1989), (Brennan and Hughes (1991), (Chung and Jo (1996), Barth et al. (2001), Kirk (2011)); disclosure quality (Lang and Lundholm (1996), Bowen et al. (2002), Irani and Karamanou (2003), Francis et al. (1997), Healy et al. (1999), Botosan and Harris (2000), Hirst et al. (1998), Bradshaw et al (2004), Lehavy et al.. (2011)); corporate governance ((Ali et al. (2007), Baik et al. (2010), Jiraporn et al. (2012)); analysts' incentives and behavioral biases (McNichols and O'Brien (1997), Das, Levine, and Sivaramakrishnan (1998), Lim (2001), Jackson (2005), Cowen et al. (2006), and Bradley et al. (2006)). In addition to prior studies not controlling for investor demand which may bias prior results, this is significant to practitioners in order to see how direct market participants influence market analyst coverage.
} 
Google Search Volume Index (GSVI) of stocks. By investigating whether analysts respond to information demand and observing whether this association is conditional of the type of investor information demand, we bridge the gap in the literature Beyer et al. (2010) show exists in our understanding of what motivates analysts coverage decisions.

We present evidence which supports the hypothesis that analysts follow IID for information. On average, analyst coverage contemporaneously increases around 10 percentage points in a month for each additional day of IID in that month; whereas analyst coverage decreases by about 0.8 percentage points in response to previous month's IID. This suggests that analysts positively respond to changes in IID during the same month of the spike in information demand, however they partially revert their coverage in the month following the increase in IID. Our results marginally support the hypothesis that analysts follow RID. On average, analyst coverage increases around 1.25 percentage points in a month for each additional day of abnormal RID in that same month; whereas analyst coverage decreases around 0.43 percentage points for an increase in RID in the previous month. This may reflect that analyst following follows larger amounts of money and satisfies potential analyst employer customers in the form of institutional investor firms. Lastly, we find evidence that analysts are more responsive to investor interest in large growth-oriented firms.

One problem with our empirical framework is the potential simultaneity issue between analyst following and investor information demand. It may be possible that analysts start following a firm, which garners investor interest, which in turn increases their demand for this information. We control for this problem in several ways. First, we use both contemporaneous and forward dependent variables in our empirical tests. The time difference between the dependent and independent variables partially alleviates this issue. Second, we split our sample 
into only analyst initiation of coverage and only analyst dropping coverage. By splitting our sample in this way, we can isolate whether investors increase in information demand led to an increase in analyst coverage, and similarly whether investors decrease in information led to analysts dropping coverage. Results in the initiation and dropping coverage support our findings of a positive association between investor demand for information and analyst coverage. This result suggests that reverse causality is not driving results, and further suggests that analyst coverage is sensitive to investor information needs.

There are several implications related to these findings. Empirical evidence suggests that analysts follow the information demand of investors. This relationship implies that, as information facilitators, analysts cover firms that investors demand higher information about, which is when the analysts information may offer the highest utility. This implication indicates that analyst coverage follows rational expectations regarding firms they cover. Additionally, analysts react more to information demand when that demand comes from sources with larger investment funds and potential future business opportunities. This may reflect analysts desire to gain favorable opinions from institutions which they may desire business with in the future. This result indicates that analysts are rationally following the money.

\section{Prior Literature and Hypotheses}

\section{Cause of Analyst Coverage}

Bhushan (1989) proposes the seminal model in which analyst following is positively associated with firm size, institutional ownership, and return volatility. Brennan and Hughes (1991) find that analyst following is greater for firms with lower share prices and coverage increases after stock splits. They argue since brokerage commission depends on the underlying share prices it encourages brokers to produce research reports on firms with low share prices. 
Chung and Jo (1996) document that analyst following is endogenously determined with firm quality. Analyst following reduces the agency cost of monitoring thereby increasing firm value. On the other hand, higher quality firms are easier to market which encourages analysts to follow high quality firms. McNichols and O’Brien (1997) propose a selection bias explanation for analyst following. They find that analysts tend to follow firms for which they have favorable views about future performance. Barth et al. (2001) find results consistent with their predictions that analysts have a greater potential for profitable private information acquisition in firms with high degree of information asymmetry, thereby leading to more profitable recommendations and higher trading commissions. In a related study, Kirk (2011) documents that firms that have greater information uncertainty and less visibility are more likely to hire a research firm.

Studies also investigate the effect of disclosure quality on analyst following. Lang and Lundholm (1996) hypothesize that voluntary disclosure is an important determinant of analyst following and forecast characteristics. Informative disclosure reduces the cost of information acquisition for analysts and hence increases their supply. Bowen et al. (2002) find that conference calls are positively associated with analyst following. Irani and Karamanou (2003) find that analyst following has decreased in the post Regulation Fair Disclosure (Reg FD) period.

Similar studies in this vein find that analyst coverage is increasing with corporate presentations (Francis et al. (1997)), firms' rating of voluntary disclosure (Healy et al. (1999)). Financial reporting complexity is another similar line of research associated with analyst coverage. Findings show that analyst following is associated with firms' decisions to include information on segment activity as part of their quarterly report (Botosan and Harris (2000)), clarity of the income effects of financial items (Hirst et al. (1998)), firms' accounting choices (Bradshaw et al. (2004)) and readability of 10-Ks (Lehavy et al. (2011)). 
Recent studies on analyst following emphasize the role of corporate governance. Ali et al. (2007) document that analyst following is increasing with family ownership since family firms make better disclosure. Baik et al. (2010) find that analyst coverage is inversely related to managerial ownership and accuracy of analysts' forecasts declines as managerial ownership increases. Jiraporn et al. (2012) report that firms with staggered boards and weaker governance experience higher analyst following. Staggered boards facilitate managerial entrenchment by insulating managers from the takeover market. As managers enjoy job security they have fewer incentives to hide information which results in less information asymmetry. Therefore, more transparent information environment is associated with greater analyst following.

Cross-country analysis of analyst following has identified some country level factors. Bushman et al. (2004) conducts factor analysis and show that analysts are less likely to follow firms in countries with less financial transparency. Chen et al. (2007) find that analyst coverage increases following cross-listing. Bae et al. (2008) report that analyst following is negatively associated with the extent to which GAAP differ between the firm's and the analyst's home countries.

Analysts' incentives and behavioral biases also play an important role in determining whether to follow a firm. McNichols and O'Brien (1997) find that analysts exhibit selection bias in coverage decisions as they tend to follow firms about which they have optimistic views. Jackson (2005) shows that analysts tend to follow firms for which they have incentives to maximize the trading volume. Cowen et al. (2006) also report that analysts are influenced by trading incentives. Moreover, Lim (2001) and Das, Levine, and Sivaramakrishnan (1998) provide evidence that analysts tend to follow stocks in an attempt to obtain investment banking business or to obtain access to private information. 


\section{Demand for Information, Analyst Coverage, and the Simultaneity Issue}

Jensen and Meckling (1976) postulate that security analysts play an important monitoring role when there exists agency problems due to the separation of ownership and control. Analysts provide monitoring service by disseminating information about firms to investors through research reports which ultimately helps investors detect opportunistic behavior by managers. Moyer et al. (1989) empirically test the monitoring hypothesis by showing a positive association between analyst following and firms' agency costs. Greater institutional ownership is therefore translated into higher demand for information from analysts. As a result, analyst following is expected to be positively associated with the proportion of institutional ownership in a firm. Bhushan (1989) also proposes that ownership structure of a firm plays an important role in determining the demand for information and analyst monitoring. Greater inside ownership reduces managerial moral hazard thereby reducing the need for analyst following.

O'Brien and Bhushan (1990) argue that analysts act as information intermediaries for both retail and institutional investors. Therefore, analysts' following of a firm provides institutional managers more information about the firm thereby inducing the institutions to hold these firms in their portfolios. On the other hand, institutions need information in order to make investment decision and also to fulfill fiduciary requirements. Hence, institutions are willing to pay for analyst reports thereby causing greater analyst following. By examining a simultaneous model of changes in analyst following and changes in institutional ownership, they show that firm size is not associated with analyst following. Ackert and Athanassakos (2003) find that analysts respond to increases in institutional holdings by increasing their optimism for a firm's earnings and institutions increase their holdings in a firm when analysts revise their earnings expectations upward. Hussain (2000) uses a sample of UK firms and employs a three stage least 
square estimation method. He finds that analyst following is positively associated with institutional ownership.

Brown et al. (2015) conclude form a survey of analysts that hedge funds are the most important clients of analysts, followed by mutual funds and retail investors. We test this conjecture empirically by modelling analyst coverage as a function of institutional ownership by different types of investors. We also test whether analysts cater to retail investors' demand by estimating analyst following as a function of Google SVI of stocks.

Hypotheses

Information is a necessary to price an asset, and analysts are a significant component of providing information (Frankel et al. (2006), Savor (2012), Louis et al. (2013) and Green et al. (2014). The more market participants involved in a given asset, the higher the demand for information and the resulting increase in information of the asset will surface. Therefore, we hypothesize that as market demand for an asset increases, which increases the demand for information, analyst coverage increases. There are two primary components of market demand for stocks, II and RI (Da, Engelberg and Gao (2011, 2014)). Proxying for RI demand, we follow Da, Engelberg and Gao (2011, 2014) and Ben-Rephael et al. (2017) and use the SVI directly related to a firm's stock. Following Ben-Rephael et al. (2017), we use the news readership measure in Bloomberg terminals as a proxy for IID.

H1: The number of analysts following a stock is positively associated retail investor interest.

H2: The number of analysts following a stock is positively associated with institutional interest.

Additionally, each of these components of information demand may have differing marginal effects on analyst coverage (Brown et al. (2015)). Therefore, we also test whether their marginal effects on analyst coverage significantly differ. The difference between the effects of 
retail versus institutional information demand on analyst following is a matter of empirical investigation, however the survey of Brown et al (2015) suggests that II will likely have a stronger influence on analyst following than RI.

H3: The marginal effect of institutional and retail investors' demand for information results in different magnitudes of analyst coverage

\section{Data, Methodology, and Preliminary Analysis}

Data

We collect data from 2010 through 2015. We use Compustat for financial statement information, CRSP for stock price information, I/B/E/S for analyst following data. Full definitions of all variables are available in the appendix. Our dependent variable is analyst following (AF) which is defined as the log of one plus the number of unique analysts following a stock in a month. Following Ben-Rephael et al. (2017), we use Google Search Volume Index (GSVI) to construct the proxy for RID ${ }^{3}$. Following their methodology, we convert their raw daily GSVI data into abnormal SVI measure. Since we are looking for abnormal attention, we first define the daily measure of abnormal SVI by comparing the raw SVI in day $t$ with the distribution of SVIs during the past 30 days. Daily abnormal SVI is then coded as 1 if the daily SVI of a ticker is greater than the $96 \%$ of the previous 30 days' SVIs, other wise 0 . Finally, we sum the number of abnormal SVI days in month and use that as our measure of retail investor information demand (RID).

We use Bloomberg news readership volume to estimate the measure for institutional IID. The variable "News_heat_read_dmax" reports the daily news readership volume of a ticker. This variable takes the values of $0,1,2,3$ or 4 if the news readership in a day is below $80 \%$, between

\footnotetext{
${ }^{3}$ We are thankful to Dr. Ryan Israelsen for providing us with their GSVI data used in the Ben-Rephael et al. (2017) paper.
} 
$80 \%$ and $90 \%, 90 \%$ and $94 \%, 94 \%$ and $96 \%$, or greater than $96 \%$ of the previous 30 days' hourly counts, respectively. Similar to the RID measure, since we are looking for abnormal attention, we want our measure of institutional information demand to pick up the months in which news readership volume experienced a spike. Therefore, we define abnormal news readership days as the days in which daily news readership measure is equal to 4 . Then we convert these daily values to monthly by counting the number of abnormal news readership days for a ticker in a month.

For robustness, we also estimate measures of abnormal information demand. Abnormal retail investor information demand (ABN_RID) is measured as RID of a month minus the median RID of the previous 6 months. Likewise, abnormal institutional investor information demand (ABN_IID) is measured as IID a month minus the median IID during the previous 6 months.

Data are taken at the monthly level when available, and when not available data are converted to monthly values from shorter intervals (i.e. daily stock returns are geometrically averaged into monthly returns). All variables are winsorized at the $1 \%$ and $99 \%$ level.

\section{Methodology}

The full primary model we testis:

$$
\begin{gathered}
a f_{\text {dif }_{i, t}}\left(a_{\text {dif }_{i, t+1}}\right)=\alpha+\beta_{1} I I D\left(A B N_{-} I I D\right)_{i, t}+\beta_{2} R I D\left(A B N_{-} R I D\right)_{i, t} \\
+\beta_{3} \text { lev }_{i, t}+\beta_{4} \text { roa }_{i, t}+\beta_{5} m b_{i, t}+\beta_{6} r d_{i, t}+\beta_{7} c f_{i, t}+\beta_{8} \text { size }_{i, t}+\beta_{9} a l p h a_{i, t}+\beta_{10} \text { resid }_{i, t}
\end{gathered}
$$

Subscript $i$ denotes the firm and subscript $t$ denotes the monthly time period. Where the dependent variable is $a f_{d i f_{i, t}}\left(a f_{d i f_{i, t+1}}\right)$, which is the analyst following. The independent variables of focus are IID $\left(A B N_{-} I I D\right)_{i, t}$, which measures the institutional investor information demand of firm $i$ (abnormal institutional investor information demand for firm i) using 
Bloomberg news readership measure, and $R I D\left(A B N_{-} R I D\right)_{i, t}$, which measures retail investor information demand for the firm i (abnormal retail investor information demand for firm i) using Google SVI. Following Ben-Rephael et al. (2017, firm level controls include: leverage, return on assets, market-to-book, research and development, operating cash flow, size (market cap), alpha (stock return performance measured through the one factor model) and risk (standard deviation of residuals estimated through the one factor model). Financial statement data are scaled by firm assets. Additionally, fixed effects are included for year and industry.

\section{Preliminary Analysis}

Table 1 presents the descriptive statistics of the data in nominal terms. There are 28,643 monthly observations in the sample. The average number of unique analysts issuing forecasts for a given firm per month in the sample is 3.74 . IID is on a 0 to 4 scale with an average value of 1.8. RID also is on a 0 to 4 scale and it has an average of 2.2. These descriptive statistics suggest that in an average month, the spike in information demand is more pronounced for the retail investors than for the institutional investors.

(Insert Table 1 about here)

Table 2 presents the correlations and significance of the correlations between variables. This table presents preliminary evidence of a significant correlation between changes in analyst following and investor information demand. RID, ABN_RID, IID, and ABN_IID are significantly and positively correlated to analyst following (AF). These results additionally suggest that IID has a relatively stronger association to AF relative to RID. However, univariate sorts do not control for relevant factors nor allow us to observe how AF initiation and dropping of coverage is affected by investor information demand.

(Insert Table 2 about here) 
Table 3 presents the high-low difference of changes in analyst following sorted by the investor interest proxy. Results suggest that analyst following is significantly higher among firms with higher investor interest, which supports the first and second hypothesis. The difference in analyst following is higher among the II interest proxies relative to the RI interest proxies. This finding supports the third hypothesis.

(Insert Table 3 about here)

\section{Regression Analysis}

Table 4 presents results for changes in analyst following regressed on retail investor information demand. Results suggest that analysts significantly increase contemporaneous coverage of a firm with increased RI interest. This supports the first hypothesis, analysts significantly increase their following of a firm when RI have higher information demand for that firm. However, when AF is measured in the proceeding time period, the estimated coefficient is marginally negative, which is conflicting with the first hypothesis. Taken together, however, the estimated coefficient of the contemporaneous estimation is roughly quardruple the size of the lead AF estimation. This suggests that analysts respond to increases in RI information demand, then have a partial reversion following the increase in investor attention. In aggregate between the two time periods, AF increases roughly $1.050 \%$ for an additional day of abnormal retail investor demand in a month.

\section{(Insert Table 4 about here)}

Table 5 presents results for changes in analyst following regressed on institutional investor information demand. Results suggest that analysts significantly increase contemporaneous coverage of a firm with increased II interest. This supports the second hypothesis, analysts significantly increase their following of a stock when II have higher 
information demand for a firm. However, when AF is measured in the proceeding time period, the estimated coefficient is marginally negative, IID becomes insignificantly positive in the proceeding time period, whereas ABN_IID becomes significantly negative, which is conflicting with the first hypothesis. However, taken together the estimated coefficient of the contemporaneous estimation is roughly twenty-five times the size of the lead AF estimation. This suggests that analysts respond to increases in II information demand, then have a partial reversion following the increase in investor attention. In aggregate between the two time periods, AF increases roughly $10 \%$ for an additional day of abnormal institutional investor demand in a month.

(Insert Table 5 about here)

In table 6, we combine both measures of investor information demand. We regress analyst following on both RID and IID. Results show that when II or RI interest in a firm increases, analysts contemporaneously increase their following of that firm. This coverage is partially reverted in the proceeding time period. However, analyst sensitivity to changes in II interest is roughly ten times as high as the analyst sensitivity to RI interest. This suggests that analysts are relatively more interested in the information demand of institutional investors than that of retail investors. These results empirically confirm the survey evidence presented by Brown et al. (2015), that analysts are most interested in the interests of institutional investors. These results imply that analysts may be chasing the money with their coverage.

(Insert Table 6 about here)

Reverse causality is a significant concern in understanding the association between analyst following and investor interest in a firm. It is possible that the analyst coverage is what ignites an investor's interest in a firm, rather than the investor's interest sparking the analyst 
following. We mitigate this concern by looking at analysts' initiation and dropping the coverage of a particular firm. In the case of initiation, there were no analysts covering the firm to garner investor interest. So in this setup there are no priors of analyst following on which investors may develop their interest in the firm. Thus reducing the reverse causality problem. Results are presented in Table 7. Results suggest that the magnitude of analyst following is stronger in the initiation and dropping sample relative to the change in overall coverage sample used above. Analysts contemporaneously increase initiations by roughly $4.06 \%$ for one more day of abnormal information demand by RIs and by $28.92 \%$ for every additional day of abnormal information demand by IIs. However, this relatively larger contemporaneous increase in initiation is followed by a relatively larger reversal in the proceeding time period. Similarly, analysts contemporaneously reduce dropping coverage of a firm by $3.74 \%$ and $29.46 \%$ for each additional day of abnormal information demand by RIs and IIS, respectively.

(Insert Table 7 about here)

Finally, we observe what sort of firm characteristics might moderate the association between analyst coverage and investor information demand. We sort firms into high-low groupings based on size, market-to-book, and RD expenditures. Results are presented in Table 8 . Results suggest that analysts are more responsive to investor interest in large, growth, and high R\&D firms. In other words, analysts tend to be more responsive to firms with characteristics similar to large tech stocks. Interestingly, $\mathrm{AF}$ is more sensitive across firm characteristics for RID than for IID. This might suggest that AF is conditionally more sensitive depending on firm characteristics which attract RI.

(Insert Table 8 about here)

\section{Conclusion}


We investigate whether analysts respond to changes in information demand of institutional and retail investors, proxied as the news readership on Bloomberg terminals and Google SVI respectively. Evidence supports the hypothesis that analyst coverage responds to II demand for information. Analysts contemporaneously increase their coverage when investor interest in a firm increases, however this coverage is partially reversed in the proceeding time period. Additionally, empirical evidence suggests that analyst following is relatively stronger in response to changes in II relative to RI interest. These results empirically support the survey evidence presented by Brown et al. (2015). Finally, results suggest that analysts are more responsive to investor interest in large growth-oriented firms.

Implications of these results are in line with prior herding behavior research as well as rational analyst behavior. Analysts choose to follow firms which have more investor interest, particularly institutional investors. This finding indicates that analysts participate in the herding of interests. Additionally, analysts put more weight on following institutional interests which have higher investment stakes, relative to retail investors, as well as potentially offering future business to the analyst's employer. The results indicate that analysts rationally follow the informational demand of investors which may benefit the analysts' choice of coverage in the future by providing the analysts' with the institution's business. 


\section{References}

Ackert, Lucy F., and George Athanassakos. "A simultaneous equations analysis of analysts' forecast bias, analyst following, and institutional ownership." Journal of Business Finance \& Accounting 30.7-8 (2003): 1017-1042.

Ali, Ashiq, Tai-Yuan Chen, and Suresh Radhakrishnan. "Corporate disclosures by family firms." Journal of Accounting and Economics 44.1 (2007): 238-286.

Bae, Kee-Hong, René M. Stulz, and Hongping Tan. "Do local analysts know more? A crosscountry study of the performance of local analysts and foreign analysts." Journal of Financial Economics 88.3 (2008): 581-606.

Baik, Bok, Jun-Koo Kang, and Jin-Mo Kim. "Local institutional investors, information asymmetries, and equity returns." Journal of Financial Economics 97.1 (2010): 81-106.

Barth, Mary E., Ron Kasznik, and Maureen F. McNichols. "Analyst coverage and intangible assets." Journal of Accounting Research 39.1 (2001): 1-34.

Beyer, Anne, Daniel A. Cohen, Thomas Z. Lys, and Beverly R. Walther. "The financial reporting environment: Review of the recent literature." Journal of Accounting and Economics 50.2 (2010): 296-343.

Bhushan, Ravi. "Firm characteristics and analyst following." Journal of Accounting and Economics 11.2 (1989): 255-274.

Botosan, Christine A., and Mary S. Harris. "Motivations for a change in disclosure frequency and its consequences: An examination of voluntary quarterly segment disclosures." Journal of Accounting Research 38.2 (2000): 329-353.

Bowen, Robert M., Angela K. Davis, and Dawn A. Matsumoto. "Do conference calls affect analysts' forecasts?." The Accounting Review 77.2 (2002): 285-316. 
Bradley, Daniel J., Bradford D. Jordan, and Jay R. Ritter. "Analyst behavior following IPOs: the “bubble period” evidence." The Review of Financial Studies 21.1 (2006): 101-133.

Bradshaw, Mark T., Brian J. Bushee, and Gregory S. Miller. "Accounting Choice, Home Bias, and US Investment in Non-US Firms." Journal of Accounting Research 42.5 (2004): 795841.

Brennan, Michael J., and Patricia J. Hughes. "Stock prices and the supply of information." The Journal of Finance 46.5 (1991): 1665-1691.

Brown, Nerissa C., Kelsey D. Wei, and Russ Wermers. "Analyst recommendations, mutual fund herding, and overreaction in stock prices." Management Science 60.1 (2013): 1-20.

Brown, Lawrence D., et al. "Inside the "Black Box" of Sell-Side Financial Analysts." Journal of Accounting Research 53.1 (2015): 1-47.

Bushman, Robert M., Joseph D. Piotroski, and Abbie J. Smith. "What determines corporate transparency?." Journal of Accounting Research 42.2 (2004): 207-252.

Carhart, Mark. “On Persistence in Mutual Fund Performance.” Journal of Finance, vol. 52 (1997): 57-82.

Chen, Feng, Ira S. Weiss, and Lin Zheng. "The predictive role of analyst coverage intensity: evidence from cross-listing in the US." Journal of Contemporary Accounting \& Economics 3.1 (2007): 34-57.

Chung, Kee H., and Hoje Jo. "The impact of security analysts' monitoring and marketing functions on the market value of firms." Journal of Financial and Quantitative Analysis 31.04 (1996): 493-512.

Cowen, Amanda, Boris Groysberg, and Paul Healy. "Which types of analyst firms are more optimistic?." Journal of Accounting and Economics 41.1 (2006): 119-146. 
Daniel, Kent. Grinblatt, Mark. Titman, Sheridan. Wermers, Russ. "Measuring Mutual Fund Performance with Characteristic-Based Benchmarks.” Journal of Finance, vol. 52 (1997): 1035-1058.

Das, Somnath, Carolyn B. Levine, and Ki Sivaramakrishnan. "Earnings predictability and bias in analysts' earnings forecasts." Accounting Review (1998): 277-294.

Firth, Michael, et al. "The client is king: do mutual fund relationships bias analyst recommendations?." Journal of Accounting Research 51.1 (2013): 165-200.

Francis, Jennifer, J. Douglas Hanna, and Donna R. Philbrick. "Management communications with securities analysts." Journal of Accounting and Economics 24.3 (1997): 363-394.

Frankel, Richard. Kothari, S.P. Weber, Joseph. "Determinants of the Informativeness of Analyst Research.” Journal of Accounting and Economics 41 (2006): 29-54.

Green, T. Clifton. Jame, Russell. Markov, Stanimir. Subasi, Musa. “Access to Management and the Informativeness of Analyst Research.” Journal of Financial Economics 114.2 (2014): 239-255.

Healy, Paul M., Amy P. Hutton, and Krishna G. Palepu. "Stock performance and intermediation changes surrounding sustained increases in disclosure*."Contemporary Accounting Research 16.3 (1999): 485-520.

Hirst, D. Eric, and Patrick E. Hopkins. "Comprehensive income reporting and analysts' valuation judgments." Journal of Accounting Research 36 (1998): 47-75.

Hussain, Simon. "Simultaneous determination of UK analyst following and institutional ownership." Accounting and Business Research 30.2 (2000): 111-124.

Irani, Afshad J., and Irene Karamanou. "Regulation fair disclosure, analyst following, and analyst forecast dispersion." Accounting Horizons 17.1 (2003): 15-29. 
Jackson, Andrew R. "Trade generation, reputation, and sell-side analysts." The Journal of Finance 60.2 (2005): 673-717.

Jensen, Michael C. "The performance of mutual funds in the period 1945-1964." The Journal of Finance 23.2 (1968): 389-416.

Jensen, Michael C., and William H. Meckling. "Theory of the firm: Managerial behavior, agency costs and ownership structure." Journal of Financial Economics 3.4 (1976): 305-360.

Jiraporn, Pornsit, Pandej Chintrakarn, and Young S. Kim. "Analyst following, staggered boards, and managerial entrenchment." Journal of Banking \& Finance 36.11 (2012): 3091-3100.

Kirk, Marcus. "Research for sale: Determinants and consequences of paid-for analyst research." Journal of Financial Economics 100.1 (2011): 182-200.

Lang, Mark H., and Russell J. Lundholm. "Corporate disclosure policy and analyst behavior." Accounting Review (1996): 467-492.

Lehavy, Reuven, Feng Li, and Kenneth Merkley. "The effect of annual report readability on analyst following and the properties of their earnings forecasts." The Accounting Review 86.3 (2011): 1087-1115.

Lim, Terence. "Rationality and analysts' forecast bias." The Journal of Finance 56.1 (2001): 369385.

Louis, Henock, Amy X. Sun, and Oktay Urcan. "Do analysts sacrifice forecast accuracy for informativeness?." Management Science 59.7 (2013): 1688-1708.

McNichols, Maureen, and Patricia C. O'Brien. "Self-selection and analyst coverage." Journal of Accounting Research 35 (1997): 167-199. 
Moyer, R. Charles, Robert E. Chatfield, and Phillip M. Sisneros. "Security analyst monitoring activity: Agency costs and information demands." Journal of Financial and Quantitative Analysis 24.04 (1989): 503-512.

O'Brien, Patricia C., and Ravi Bhushan. "Analyst following and institutional ownership." Journal of Accounting Research (1990): 55-76.

Savor, Pavel G. "Stock returns after major price shocks: The impact of information." Journal of Financial Economics 106.3 (2012): 635-659.

Wermers, Russ. "Mutual fund performance: An empirical decomposition into stock-picking talent, style, transactions costs, and expenses." The Journal of Finance 55.4 (2000): 1655-1695.

Wermers, Russ. "Mutual fund herding and the impact on stock prices." The Journal of Finance 54.2 (1999): 581-622. 


\section{Table 1}

This table reports summary statistics of the variables used in this study. The variables are defined in the Appendix. Data are gathered from 2010 to 2015.

\begin{tabular}{lcccccc}
\hline & $\mathbf{N}$ & Mean & SD & P25 & Median & P75 \\
\hline AF & 28643 & 1.641 & 0.801 & 0.693 & 1.609 & 2.303 \\
\hline RID & 28643 & 2.165 & 1.819 & 1.000 & 2.000 & 3.000 \\
\hline ABN_RID & 28643 & 0.147 & 2.066 & -1.500 & 0.000 & 1.500 \\
\hline IID & 28643 & 1.807 & 2.030 & 0.000 & 1.000 & 3.000 \\
\hline ABN_IID & 28643 & 0.365 & 1.672 & -0.500 & 0.000 & 1.000 \\
\hline LEV & 28643 & 0.232 & 0.183 & 0.091 & 0.214 & 0.331 \\
\hline ROA & 28643 & 0.037 & 0.028 & 0.025 & 0.035 & 0.049 \\
\hline MB & 28643 & 2.069 & 1.202 & 1.305 & 1.689 & 2.369 \\
\hline RD & 28643 & 0.007 & 0.013 & 0.000 & 0.000 & 0.008 \\
\hline CF & 28643 & 0.057 & 0.071 & 0.015 & 0.049 & 0.097 \\
\hline SIZE & 28643 & 8.076 & 1.581 & 6.978 & 8.032 & 9.079 \\
\hline ALPHA & 28643 & -0.002 & 0.218 & -0.122 & 0.003 & 0.131 \\
\hline RESID & 28643 & 1.608 & 0.791 & 1.044 & 1.415 & 1.957 \\
\hline
\end{tabular}




\section{Table 2}

This table reports the correlations among the variables used in this study. The variables are defined in the Appendix. Data are gathered from 2010 to 2015 .

\begin{tabular}{|c|c|c|c|c|c|c|c|c|c|c|c|c|c|}
\hline & $\mathrm{AF}$ & RID & ABN_RID & IID & ABN_ID & LEV & ROA & MB & RD & $\mathrm{CF}$ & SIZE & ALPHA & RESID \\
\hline \multirow[t]{2}{*}{$\mathrm{AF}$} & 1.000 & 0.057 & 0.046 & 0.398 & 0.228 & 0.041 & 0.053 & 0.020 & -0.029 & 0.093 & 0.282 & -0.030 & -0.070 \\
\hline & & $<.0001$ & $<.0001$ & $<.0001$ & $<.0001$ & $<.0001$ & $<.0001$ & 0.0007 & $<.0001$ & $<.0001$ & $<.0001$ & $<.0001$ & $<.0001$ \\
\hline \multirow[t]{2}{*}{ RID } & 0.057 & 1.000 & 0.904 & 0.048 & 0.050 & -0.004 & -0.003 & 0.007 & 0.004 & 0.005 & 0.017 & 0.004 & -0.016 \\
\hline & $<.0001$ & & $<.0001$ & $<.0001$ & $<.0001$ & 0.4866 & 0.5674 & 0.2571 & 0.465 & 0.4436 & 0.0042 & 0.4946 & 0.0083 \\
\hline \multirow[t]{2}{*}{ ABN_RID } & 0.046 & 0.904 & 1.000 & 0.059 & 0.038 & -0.001 & 0.004 & 0.005 & -0.001 & -0.002 & 0.020 & 0.001 & -0.017 \\
\hline & $<.0001$ & $<.0001$ & & $<.0001$ & $<.0001$ & 0.8298 & 0.5073 & 0.3786 & 0.8736 & 0.7311 & 0.0008 & 0.8852 & 0.004 \\
\hline \multirow[t]{2}{*}{ IID } & 0.398 & 0.048 & 0.059 & 1.000 & 0.679 & 0.104 & 0.013 & 0.051 & 0.015 & 0.038 & 0.391 & -0.006 & -0.053 \\
\hline & $<.0001$ & $<.0001$ & $<.0001$ & & $<.0001$ & $<.0001$ & 0.0334 & $<.0001$ & 0.0097 & $<.0001$ & $<.0001$ & 0.2939 & $<.0001$ \\
\hline \multirow[t]{2}{*}{ ABN_IID } & 0.228 & 0.050 & 0.038 & 0.679 & 1.000 & -0.001 & 0.003 & 0.002 & 0.009 & -0.007 & 0.019 & 0.019 & 0.007 \\
\hline & $<.0001$ & $<.0001$ & $<.0001$ & $<.0001$ & & 0.8094 & 0.5916 & 0.7204 & 0.1497 & 0.2645 & 0.0011 & 0.0016 & 0.2675 \\
\hline \multirow[t]{2}{*}{ LEV } & 0.041 & -0.004 & -0.001 & 0.104 & -0.001 & 1.000 & -0.133 & -0.016 & 0.013 & -0.163 & 0.212 & 0.006 & -0.031 \\
\hline & $<.0001$ & 0.4866 & 0.8298 & $<.0001$ & 0.8094 & & $<.0001$ & 0.0068 & 0.0298 & $<.0001$ & $<.0001$ & 0.2745 & $<.0001$ \\
\hline \multirow[t]{2}{*}{ ROA } & 0.053 & -0.003 & 0.004 & 0.013 & 0.003 & -0.133 & 1.000 & -0.181 & -0.582 & 0.698 & 0.251 & 0.047 & -0.263 \\
\hline & $<.0001$ & 0.5674 & 0.5073 & 0.0334 & 0.5916 & $<.0001$ & & $<.0001$ & $<.0001$ & $<.0001$ & $<.0001$ & $<.0001$ & $<.0001$ \\
\hline \multirow[t]{2}{*}{ MB } & 0.020 & 0.007 & 0.005 & 0.051 & 0.002 & -0.016 & -0.181 & 1.000 & 0.558 & -0.230 & -0.201 & 0.145 & 0.061 \\
\hline & 0.0007 & 0.2571 & 0.3786 & $<.0001$ & 0.7204 & 0.0068 & $<.0001$ & & $<.0001$ & $<.0001$ & $<.0001$ & $<.0001$ & $<.0001$ \\
\hline \multirow[t]{2}{*}{ RD } & -0.029 & 0.004 & -0.001 & 0.015 & 0.009 & 0.013 & -0.582 & 0.558 & 1.000 & -0.512 & -0.279 & 0.041 & 0.207 \\
\hline & $<.0001$ & 0.465 & 0.8736 & 0.0097 & 0.1497 & 0.0298 & $<.0001$ & $<.0001$ & & $<.0001$ & $<.0001$ & $<.0001$ & $<.0001$ \\
\hline \multirow[t]{2}{*}{$\mathrm{CF}$} & 0.093 & 0.005 & -0.002 & 0.038 & -0.007 & -0.163 & 0.698 & -0.230 & -0.512 & 1.000 & 0.196 & 0.004 & -0.195 \\
\hline & $<.0001$ & 0.4436 & 0.7311 & $<.0001$ & 0.2645 & $<.0001$ & $<.0001$ & $<.0001$ & $<.0001$ & & $<.0001$ & 0.4906 & $<.0001$ \\
\hline \multirow[t]{2}{*}{ SIZE } & 0.282 & 0.017 & 0.020 & 0.391 & 0.019 & 0.212 & 0.251 & -0.201 & -0.279 & 0.196 & 1.000 & 0.010 & -0.441 \\
\hline & $<.0001$ & 0.0042 & 0.0008 & $<.0001$ & 0.0011 & $<.0001$ & $<.0001$ & $<.0001$ & $<.0001$ & $<.0001$ & & 0.0898 & $<.0001$ \\
\hline \multirow[t]{2}{*}{ ALPHA } & -0.030 & 0.004 & 0.001 & -0.006 & 0.019 & 0.006 & 0.047 & 0.145 & 0.041 & 0.004 & 0.010 & 1.000 & -0.037 \\
\hline & $<.0001$ & 0.4946 & 0.8852 & 0.2939 & 0.0016 & 0.2745 & $<.0001$ & $<.0001$ & $<.0001$ & 0.4906 & 0.0898 & & $<.0001$ \\
\hline \multirow[t]{2}{*}{ RESID } & -0.070 & -0.016 & -0.017 & -0.053 & 0.007 & -0.031 & -0.263 & 0.061 & 0.207 & -0.195 & -0.441 & -0.037 & 1.000 \\
\hline & $<.0001$ & 0.0083 & 0.004 & $<.0001$ & 0.2675 & $<.0001$ & $<.0001$ & $<.0001$ & $<.0001$ & $<.0001$ & $<.0001$ & $<.0001$ & \\
\hline
\end{tabular}


Table 3

This table reports univariate tests of the difference in analyst following between high and low investor information demand categories. Data are gathered from 2010 to 2015 . *,*, and $* * *$ indicate significance at the $10 \%, 5 \%$, and $1 \%$, respectively.

\begin{tabular}{lccc}
\hline & \multicolumn{2}{c}{ Mean of Analyst Following (AF) } & Difference \\
\cline { 2 - 4 } & Low & High & $(\mathrm{t}$ stat $)$ \\
\hline RID & 1.5817 & 1.7102 & $0.1285^{* * *}$ \\
& & & 9.1823 \\
\hline ABN_RID & 1.6 & 1.7057 & $0.1057^{* * *}$ \\
& & & 7.7612 \\
\hline IID & 1.1759 & 2.0973 & $0.9214^{* * *}$ \\
& & & 79.9037 \\
\hline ABN_IID & 1.5185 & 1.9508 & $0.4323^{* * *}$ \\
& & & 32.4022 \\
\hline
\end{tabular}




\section{Table 4}

This table reports results from the regression of analyst following on retail investor information demand. Analyst following (AF) is measured as the log of number of analysts following a firm. In columns (1) and (3) retail investor information demand (RID) is estimated as the number of days in a month a ticker has experienced abnormal Google SVI. In columns (2) and (4) abnormal retail investor information demand (ABN_RID) is estimated as the difference between current month RID and median monthly RID during the last 6 months. Description of the control variables is provided in Appendix. Data are gathered from 2010 to 2015. t-stats based on robust standard errors adjusted for heteroskedasticity are reported in parentheses. $*, * *$, and $* * *$ indicate significance at the $10 \%, 5 \%$, and $1 \%$, respectively.

\begin{tabular}{|c|c|c|c|c|}
\hline & (1) & (2) & (3) & (4) \\
\hline & $\mathrm{AF}$ & $\mathrm{AF}$ & $\mathrm{AF}_{\mathrm{t}+1}$ & $\mathrm{AF}_{\mathrm{t}+1}$ \\
\hline RID & $\begin{array}{c}0.0201 * * * \\
(8.451)\end{array}$ & & $\begin{array}{c}-0.0045^{*} \\
(-1.876)\end{array}$ & \\
\hline ABN_RID & & $\begin{array}{c}0.0133^{* * * *} \\
(6.608)\end{array}$ & & $\begin{array}{c}-0.0040 * * \\
(-1.979)\end{array}$ \\
\hline LEV & $\begin{array}{l}-0.0025 \\
(-0.089)\end{array}$ & $\begin{array}{l}-0.0030 \\
(-0.104)\end{array}$ & $\begin{array}{l}-0.0077 \\
(-0.269)\end{array}$ & $\begin{array}{l}-0.0078 \\
(-0.270)\end{array}$ \\
\hline ROA & $\begin{array}{l}-0.1069 \\
(-0.514)\end{array}$ & $\begin{array}{l}-0.1301 \\
(-0.625)\end{array}$ & $\begin{array}{l}-0.0464 \\
(-0.221)\end{array}$ & $\begin{array}{l}-0.0411 \\
(-0.195)\end{array}$ \\
\hline MB & $\begin{array}{c}0.0660 * * * \\
(13.895)\end{array}$ & $\begin{array}{c}0.0666 * * * \\
(14.007)\end{array}$ & $\begin{array}{c}0.0657 * * * \\
(13.672)\end{array}$ & $\begin{array}{c}0.0656^{* * * *} \\
(13.644)\end{array}$ \\
\hline RD & $\begin{array}{c}2.4686 * * * \\
(5.453)\end{array}$ & $\begin{array}{c}2.4625 * * * \\
(5.436)\end{array}$ & $\begin{array}{c}3.0401 * * * \\
(6.629)\end{array}$ & $\begin{array}{c}3.0431 * * * * \\
(6.635)\end{array}$ \\
\hline $\mathrm{CF}$ & $\begin{array}{c}0.3180 * * * \\
(4.108)\end{array}$ & $\begin{array}{c}0.3188 * * * \\
(4.116)\end{array}$ & $\begin{array}{c}0.2084 * * * \\
(2.665)\end{array}$ & $\begin{array}{c}0.2085^{* * * *} \\
(2.666)\end{array}$ \\
\hline SIZE & $\begin{array}{c}0.1820 * * * \\
(50.422)\end{array}$ & $\begin{array}{c}0.1820 * * * \\
(50.348)\end{array}$ & $\begin{array}{c}0.1815^{* * * *} \\
(49.900)\end{array}$ & $\begin{array}{c}0.1815^{* * * *} \\
(49.904)\end{array}$ \\
\hline ALPHA & $\begin{array}{c}-0.0936 * * * \\
(-4.892)\end{array}$ & $\begin{array}{c}-0.0933 * * * \\
(-4.879)\end{array}$ & $\begin{array}{c}-0.0647 * * * \\
(-3.376)\end{array}$ & $\begin{array}{c}-0.0647 * * * * \\
(-3.377)\end{array}$ \\
\hline RESID & $\begin{array}{c}0.0535 * * * \\
(8.230)\end{array}$ & $\begin{array}{c}0.0531 * * * \\
(8.168)\end{array}$ & $\begin{array}{c}0.0464 * * * \\
(7.069)\end{array}$ & $\begin{array}{c}0.0465 * * * * \\
(7.077)\end{array}$ \\
\hline CONS & $\begin{array}{c}-0.1251^{* * * *} \\
(-3.466) \\
\end{array}$ & $\begin{array}{c}-0.0835^{* *} \\
(-2.334) \\
\end{array}$ & $\begin{array}{l}-0.0599 \\
(-1.643) \\
\end{array}$ & $\begin{array}{c}-0.0692^{*} \\
(-1.914) \\
\end{array}$ \\
\hline Industry FE & Yes & Yes & Yes & Yes \\
\hline Year FE & Yes & Yes & Yes & Yes \\
\hline adj. R-sq & 0.188 & 0.188 & 0.190 & 0.190 \\
\hline $\mathrm{N}$ & 28643 & 28643 & 28369 & 28369 \\
\hline
\end{tabular}




\section{Table 5}

This table reports results from the regression of analyst following on institutional investor information demand. Analyst following (AF) is measured as the log of number of analysts following a firm. In columns (1) and (3) institutional investor information demand (IID) is estimated as the number of days in a month a ticker has experienced abnormal news readership on Bloomberg terminals. In columns (2) and (4) abnormal institutional investor information demand (ABN_IID) is estimated as the difference between current month IID and median monthly IID during the last 6 months. Description of the control variables is provided in Appendix. Data are gathered from 2010 to 2015. t-stats based on robust standard errors adjusted for heteroskedasticity are reported in parentheses. $*, * *$, and $* * *$ indicate significance at the $10 \%, 5 \%$, and $1 \%$, respectively.

\begin{tabular}{|c|c|c|c|c|}
\hline & (1) & (2) & (3) & (4) \\
\hline & $\mathrm{AF}$ & $\mathrm{AF}$ & $\mathrm{AF}_{\mathrm{t}+1}$ & $\mathrm{AF}_{\mathrm{t}+1}$ \\
\hline IID & $\begin{array}{c}0.1179^{* * * *} \\
(43.814)\end{array}$ & & $\begin{array}{l}0.0044 \\
(1.600)\end{array}$ & \\
\hline ABN_IID & & $\begin{array}{c}0.1019 * * * * \\
(39.071)\end{array}$ & & $\begin{array}{c}-0.0063^{* *} \\
(-2.393)\end{array}$ \\
\hline LEV & $\begin{array}{l}0.0401 \\
(1.451)\end{array}$ & $\begin{array}{l}-0.0048 \\
(-0.174)\end{array}$ & $\begin{array}{l}-0.0056 \\
(-0.194)\end{array}$ & $\begin{array}{l}-0.0073 \\
(-0.253)\end{array}$ \\
\hline ROA & $\begin{array}{l}0.0170 \\
(0.084)\end{array}$ & $\begin{array}{l}-0.2155 \\
(-1.062)\end{array}$ & $\begin{array}{l}-0.0366 \\
(-0.174)\end{array}$ & $\begin{array}{r}-0.0366 \\
(-0.174)\end{array}$ \\
\hline MB & $\begin{array}{c}0.0357 * * * \\
(7.766)\end{array}$ & $\begin{array}{c}0.0640 * * * \\
(13.924)\end{array}$ & $\begin{array}{c}0.0645^{* * * *} \\
(13.282)\end{array}$ & $\begin{array}{c}0.0658^{* * * *} \\
(13.680)\end{array}$ \\
\hline RD & $\begin{array}{c}1.3119 * * * \\
(3.042)\end{array}$ & $\begin{array}{c}2.2711^{* * * *} \\
(5.213)\end{array}$ & $\begin{array}{c}2.9916 * * * \\
(6.515)\end{array}$ & $\begin{array}{c}3.0486^{* * * *} \\
(6.651)\end{array}$ \\
\hline $\mathrm{CF}$ & $\begin{array}{c}0.3221 * * * \\
(4.335)\end{array}$ & $\begin{array}{c}0.3938 * * * * \\
(5.252)\end{array}$ & $\begin{array}{c}0.2075^{* * * *} \\
(2.654)\end{array}$ & $\begin{array}{c}0.2031 * * * * \\
(2.597)\end{array}$ \\
\hline SIZE & $\begin{array}{c}0.0941 * * * \\
(23.550)\end{array}$ & $\begin{array}{c}0.1792 * * * * \\
(50.846)\end{array}$ & $\begin{array}{c}0.1781^{* * * *} \\
(43.205)\end{array}$ & $\begin{array}{c}0.1816^{* * * *} \\
(49.895)\end{array}$ \\
\hline ALPHA & $\begin{array}{c}-0.0836 * * * * \\
(-4.516)\end{array}$ & $\begin{array}{c}-0.0987 * * * * \\
(-5.280)\end{array}$ & $\begin{array}{c}-0.0645 * * * \\
(-3.366)\end{array}$ & $\begin{array}{c}-0.0644 * * * \\
(-3.362)\end{array}$ \\
\hline RESID & $\begin{array}{l}0.0027 \\
(0.426)\end{array}$ & $\begin{array}{c}0.0517 * * * * \\
(8.108)\end{array}$ & $\begin{array}{c}0.0447 * * * \\
(6.719)\end{array}$ & $\begin{array}{c}0.0466 * * * * \\
(7.099)\end{array}$ \\
\hline CONS & $\begin{array}{c}0.5523 * * * \\
(14.804)\end{array}$ & $\begin{array}{c}-0.0876^{* *} \\
(-2.506)\end{array}$ & $\begin{array}{l}-0.0452 \\
(-1.170) \\
\end{array}$ & $\begin{array}{c}-0.0687^{*} \\
(-1.900)\end{array}$ \\
\hline Industry FE & Yes & Yes & Yes & Yes \\
\hline Year FE & Yes & Yes & Yes & Yes \\
\hline adj. R-sq & 0.246 & 0.236 & 0.189 & 0.190 \\
\hline $\mathrm{N}$ & 28643 & 28643 & 28369 & 28369 \\
\hline
\end{tabular}




\section{Table 6}

This table reports results from the regression of analyst following on retail and institutional investor information demand. Analyst following (AF) is measured as the log of number of analysts following a firm. In columns (1) and (3) retail investor information demand (RID) is estimated as the number of days in a month a ticker has experienced abnormal Google SVI, and institutional investor information demand (IID) is estimated as the number of days in a month a ticker has experienced abnormal news readership on Bloomberg terminals. In columns (2) and (4) abnormal retail investor information demand (ABN_RID) is estimated as the difference between current month RID and median monthly RID during the last 6 months, and abnormal institutional investor information demand (ABN_IID) is estimated as the difference between current month IID and median monthly IID during the last 6 months. Description of the control variables is provided in Appendix. Data are gathered from 2010 to 2015. t-stats based on robust standard errors adjusted for heteroskedasticity are reported in parentheses. *, **, and *** indicate significance at the $10 \%, 5 \%$, and $1 \%$, respectively.

\begin{tabular}{|c|c|c|c|c|}
\hline & $(1)$ & (2) & (3) & (4) \\
\hline & $\mathrm{AF}$ & $\mathrm{AF}$ & $\mathrm{AF}_{\mathrm{t}+1}$ & $\mathrm{AF}_{\mathrm{t}+1}$ \\
\hline RID & $\begin{array}{c}0.0152 * * * \\
(6.681)\end{array}$ & & $\begin{array}{c}-0.0047 * \\
(-1.958)\end{array}$ & \\
\hline IID & $\begin{array}{c}0.1171 * * * \\
(43.562)\end{array}$ & & $\begin{array}{c}0.0046^{*} \\
(1.686)\end{array}$ & \\
\hline ABN_RID & & $\begin{array}{c}0.0098 * * * \\
(5.033)\end{array}$ & & $\begin{array}{c}-0.0038 * \\
(-1.877)\end{array}$ \\
\hline ABN_IID & & $\begin{array}{c}0.1014 * * * \\
(38.883)\end{array}$ & & $\begin{array}{c}-0.0061 * * \\
(-2.319)\end{array}$ \\
\hline LEV & $\begin{array}{l}0.0414 \\
(1.500)\end{array}$ & $\begin{array}{l}-0.0036 \\
(-0.129)\end{array}$ & $\begin{array}{l}-0.0060 \\
(-0.208)\end{array}$ & $\begin{array}{l}-0.0077 \\
(-0.269)\end{array}$ \\
\hline ROA & $\begin{array}{l}0.0315 \\
(0.157)\end{array}$ & $\begin{array}{l}-0.2171 \\
(-1.070)\end{array}$ & $\begin{array}{l}-0.0410 \\
(-0.195)\end{array}$ & $\begin{array}{l}-0.0360 \\
(-0.171)\end{array}$ \\
\hline MB & $\begin{array}{c}0.0355^{* * * *} \\
(7.730)\end{array}$ & $\begin{array}{c}0.0640 * * * \\
(13.949)\end{array}$ & $\begin{array}{c}0.0645^{* * * *} \\
(13.299)\end{array}$ & $\begin{array}{c}0.0657 * * * \\
(13.680)\end{array}$ \\
\hline $\mathrm{RD}$ & $\begin{array}{c}1.3068 * * * \\
(3.032)\end{array}$ & $\begin{array}{c}2.2553 * * * \\
(5.178)\end{array}$ & $\begin{array}{c}2.9941 * * * \\
(6.521)\end{array}$ & $\begin{array}{c}3.0554 * * * \\
(6.665)\end{array}$ \\
\hline $\mathrm{CF}$ & $\begin{array}{c}0.3193 * * * \\
(4.301)\end{array}$ & $\begin{array}{c}0.3913 * * * \\
(5.221)\end{array}$ & $\begin{array}{c}0.2084 * * * \\
(2.665)\end{array}$ & $\begin{array}{c}0.2041 * * * \\
(2.610)\end{array}$ \\
\hline SIZE & $\begin{array}{c}0.0943 * * * \\
(23.674)\end{array}$ & $\begin{array}{c}0.1789 * * * \\
(50.882)\end{array}$ & $\begin{array}{c}0.1780 * * * \\
(43.191)\end{array}$ & $\begin{array}{c}0.1817 * * * * \\
(49.930)\end{array}$ \\
\hline ALPHA & $\begin{array}{c}-0.0841 * * * \\
(-4.542)\end{array}$ & $\begin{array}{c}-0.0989 * * * \\
(-5.291)\end{array}$ & $\begin{array}{c}-0.0643 * * * \\
(-3.359)\end{array}$ & $\begin{array}{c}-0.0644 * * * \\
(-3.359)\end{array}$ \\
\hline RESID & $\begin{array}{l}0.0036 \\
(0.560)\end{array}$ & $\begin{array}{c}0.0520 * * * \\
(8.155)\end{array}$ & $\begin{array}{c}0.0444 * * * \\
(6.680)\end{array}$ & $\begin{array}{c}0.0465 * * * \\
(7.086)\end{array}$ \\
\hline CONS & $\begin{array}{c}0.5173 * * * \\
(13.759)\end{array}$ & $\begin{array}{c}-0.0870^{* *} \\
(-2.496)\end{array}$ & $\begin{array}{l}-0.0344 \\
(-0.884)\end{array}$ & $\begin{array}{c}-0.0689 * \\
(-1.906)\end{array}$ \\
\hline Industry FE & Yes & Yes & Yes & Yes \\
\hline Year FE & Yes & Yes & Yes & Yes \\
\hline adj. R-sq & 0.247 & 0.237 & 0.190 & 0.190 \\
\hline $\mathrm{N}$ & 28643 & 28643 & 28369 & 28369 \\
\hline
\end{tabular}




\section{Table 7}

This table reports results from the logit regression of initiation and drop in analyst following on retail and institutional investor information demand. Initiation of analyst following (INIT) is a dummy variable which takes value of 1 if there was at least 1 analyst started following the firm, 0 otherwise. Drop in analyst following (DROP) is a dummy variable which takes value of 1 if there was at least 1 analyst terminated following the firm, 0 otherwise. Retail investor information demand (RID) is estimated as the number of days in a month a ticker has experienced abnormal Google SVI, and institutional investor information demand (IID) is estimated as the number of days in a month a ticker has experienced abnormal news readership on Bloomberg terminals. Abnormal retail investor information demand (ABN_RID) is estimated as the difference between current month RID and median monthly RID during the last 6 months, and abnormal institutional investor information demand (ABN_IID) is estimated as the difference between current month IID and median monthly IID during the last 6 months. Description of the control variables is provided in Appendix. Data are gathered from 2010 to 2015. t-stats based on robust standard errors adjusted for heteroskedasticity are reported in parentheses. *,**, and *** indicate significance at the $10 \%, 5 \%$, and $1 \%$, respectively.

\begin{tabular}{|c|c|c|c|c|c|c|c|c|}
\hline & $(1)$ & $(2)$ & (3) & $(4)$ & $(5)$ & $(6)$ & $(7)$ & $(8)$ \\
\hline & INIT & INIT & DROP & DROP & INIT $_{\mathrm{t}+1}$ & $\mathrm{INIT}_{\mathrm{t}+1}$ & $\mathrm{DROP}_{\mathrm{t}+1}$ & $\mathrm{DROP}_{\mathrm{t}+1}$ \\
\hline RID & $\begin{array}{c}0.0406 * * * \\
(6.055)\end{array}$ & & $\begin{array}{c}-0.0374 * * * \\
(-5.497)\end{array}$ & & $\begin{array}{c}-0.0250 * * * \\
(-3.736)\end{array}$ & & $\begin{array}{c}0.0296 * * * \\
(4.460)\end{array}$ & \\
\hline IID & $\begin{array}{c}0.2892 * * * \\
(34.981)\end{array}$ & & $\begin{array}{c}-0.2946 * * * \\
(-34.252)\end{array}$ & & $\begin{array}{c}-0.1335^{* * * *} \\
(-17.604)\end{array}$ & & $\begin{array}{c}0.1829 * * * * \\
(24.056)\end{array}$ & \\
\hline ABN_RID & & $\begin{array}{c}0.0281 * * * \\
(4.953)\end{array}$ & & $\begin{array}{c}-0.0256 * * * \\
(-4.466)\end{array}$ & & $\begin{array}{c}-0.0167 * * * \\
(-2.973)\end{array}$ & & $\begin{array}{c}0.0186^{* * *} * \\
(3.312)\end{array}$ \\
\hline ABN_IID & & $\begin{array}{c}0.2835^{* * *} \\
(33.975)\end{array}$ & & $\begin{array}{c}-0.2952 * * * \\
(-33.766)\end{array}$ & & $\begin{array}{c}-0.1421 * * * \\
(-18.992)\end{array}$ & & $\begin{array}{c}0.1871 \text { *** } \\
(24.531)\end{array}$ \\
\hline LEV & $\begin{array}{c}0.3097 * * * \\
(4.265)\end{array}$ & $\begin{array}{c}0.2121 * * * \\
(2.919)\end{array}$ & $\begin{array}{c}-0.1353^{*} \\
(-1.850)\end{array}$ & $\begin{array}{l}-0.0373 \\
(-0.511)\end{array}$ & $\begin{array}{c}0.1273 * \\
(1.779)\end{array}$ & $\begin{array}{c}0.1700 * * \\
(2.377)\end{array}$ & & $\begin{array}{l}-0.0200 \\
(-0.278)\end{array}$ \\
\hline ROA & $\begin{array}{l}0.3181 \\
(0.542)\end{array}$ & $\begin{array}{l}-0.2417 \\
(-0.409)\end{array}$ & $\begin{array}{l}0.7825 \\
(1.328)\end{array}$ & $\begin{array}{c}1.3648 * * \\
(2.323)\end{array}$ & $\begin{array}{l}0.3240 \\
(0.556)\end{array}$ & $\begin{array}{l}0.6022 \\
(1.036)\end{array}$ & $\begin{array}{l}0.4779 \\
(0.828)\end{array}$ & $\begin{array}{l}0.1154 \\
(0.199)\end{array}$ \\
\hline MB & $\begin{array}{l}-0.0121 \\
(-0.972)\end{array}$ & $\begin{array}{r}0.0582 \\
(4.72\end{array}$ & $\begin{array}{c}0.1209 * * * \\
(9.725)\end{array}$ & $\begin{array}{r}0.0492 \\
(4.02\end{array}$ & $\begin{array}{c}0.1009 * * * \\
(8.255)\end{array}$ & $\begin{array}{c}0.0686^{* * * *} \\
(5.692)\end{array}$ & & $\begin{array}{c}0.0325 * * * \\
(2.694)\end{array}$ \\
\hline $\mathrm{RD}$ & $\begin{array}{l}-0.9106 \\
(-0.823)\end{array}$ & $\begin{array}{l}0.6836 \\
(0.619)\end{array}$ & $\begin{array}{c}2.9731 * * * \\
(2.694)\end{array}$ & $\begin{array}{l}1.3707 \\
(1.249)\end{array}$ & $\begin{array}{c}2.0756^{*} \\
(1.912)\end{array}$ & $\begin{array}{l}1.3674 \\
(1.263)\end{array}$ & $\begin{array}{l}-0.5725 \\
(-0.529)\end{array}$ & \\
\hline $\mathrm{CF}$ & $\begin{array}{c}0.3756^{*} \\
(1.739)\end{array}$ & $\begin{array}{c}0.6584 * * * \\
(3.040)\end{array}$ & $\begin{array}{c}-0.5959 * * * \\
(-2.752)\end{array}$ & $\begin{array}{c}-0.8808 * * * \\
(-4.075)\end{array}$ & $\begin{array}{l}-0.0320 \\
(-0.150)\end{array}$ & $\begin{array}{l}-0.1734 \\
(-0.813)\end{array}$ & $\begin{array}{l}-0.0486 \\
(-0.229)\end{array}$ & $\begin{array}{l}0.1390 \\
(0.651)\end{array}$ \\
\hline SIZE & $\begin{array}{c}-0.0817 * * * \\
(-7.412)\end{array}$ & $\begin{array}{c}0.1308 * * * \\
(13.750)\end{array}$ & $\begin{array}{c}0.3083 * * * \\
(26.979)\end{array}$ & $\begin{array}{c}0.0913 * * * \\
(9.620)\end{array}$ & $\begin{array}{c}0.2474 * * * \\
(22.456)\end{array}$ & $\begin{array}{c}0.1494 * * * \\
(16.061)\end{array}$ & $\begin{array}{c}-0.0676^{* * * *} \\
(-6.219)\end{array}$ & $\begin{array}{c}0.0671 * * * \\
(7.202)\end{array}$ \\
\hline ALPHA & $\begin{array}{l}-0.0150 \\
(-0.258)\end{array}$ & $\begin{array}{l}-0.0545 \\
(-0.940)\end{array}$ & $\begin{array}{c}-0.1245^{* *} \\
(-2.148)\end{array}$ & $\begin{array}{l}-0.0839 \\
(-1.450)\end{array}$ & $\begin{array}{l}-0.0621 \\
(-1.088)\end{array}$ & $\begin{array}{l}-0.0436 \\
(-0.764)\end{array}$ & $\begin{array}{l}-0.0318 \\
(-0.555)\end{array}$ & $\begin{array}{l}-0.0573 \\
(-0.999)\end{array}$ \\
\hline RESID & $\begin{array}{c}-0.1287 * * * \\
(-6.831)\end{array}$ & $\begin{array}{l}0.0153 \\
(0.835)\end{array}$ & $\begin{array}{c}0.1691 * * * \\
(9.072)\end{array}$ & $\begin{array}{l}0.0226 \\
(1.234)\end{array}$ & $\begin{array}{c}0.1028 * * * \\
(5.621)\end{array}$ & $\begin{array}{c}0.0359 * * \\
(1.998)\end{array}$ & $\begin{array}{c}-0.0801 * * * \\
(-4.324)\end{array}$ & $\begin{array}{l}0.0114 \\
(0.628)\end{array}$ \\
\hline CONS & $\begin{array}{c}0.3209 * * \\
(2.454)\end{array}$ & $\begin{array}{c}-1.6458 * * * \\
(-13.555)\end{array}$ & $\begin{array}{c}-3.0119 * * * \\
(-22.197)\end{array}$ & $\begin{array}{c}-0.9843 * * * \\
(-8.166)\end{array}$ & $\begin{array}{c}-2.2799 * * * \\
(-17.643)\end{array}$ & $\begin{array}{c}-1.3788 * * * \\
(-11.740) \\
\end{array}$ & $\begin{array}{r}0.0210 \\
(0.163) \\
\end{array}$ & $\begin{array}{c}-1.2262 * * * \\
(-10.248)\end{array}$ \\
\hline Year FE & Yes & Yes & Yes & Yes & Yes & Yes & Yes & Yes \\
\hline $\mathrm{N}$ & 28643 & 28643 & 28643 & 28643 & 28369 & 28369 & 28369 & 28369 \\
\hline
\end{tabular}




\section{Table 8}

This table reports results from the cross sectional regression of analyst following on retail and institutional investor information demand. Sample is split by size in columns (1) and (2), market-to-book ratio in columns (3) and (4), R\&D expenditure in columns (5) and (6). Analyst following (AF) is measured as the log of number of analysts following a firm. Retail investor information demand (RID) is estimated as the number of days in a month a ticker has experienced abnormal Google SVI, and institutional investor information demand (IID) is estimated as the number of days in a month a ticker has experienced abnormal news readership on Bloomberg terminals. Description of the control variables is provided in Appendix. Data are gathered from 2010 to 2015. t-stats based on robust standard errors adjusted for heteroskedasticity are reported in parentheses. *,**, and *** indicate significance at the $10 \%, 5 \%$, and $1 \%$, respectively.

\begin{tabular}{|c|c|c|c|c|c|c|}
\hline & (1) & (2) & (3) & (4) & (5) & (6) \\
\hline & $\mathrm{AF}$ & $\mathrm{AF}$ & $\mathrm{AF}$ & $\mathrm{AF}$ & $\mathrm{AF}$ & $\mathrm{AF}$ \\
\hline & Small & Large & Low & High & Low & High \\
\hline & Size & Size & $\mathrm{MB}$ & $\mathrm{MB}$ & $\mathrm{R} \& \mathrm{D}$ & $\mathrm{R} \& \mathrm{D}$ \\
\hline \multirow[t]{2}{*}{ RID } & -0.0014 & $0.0314 * * *$ & 0.0055 & $0.0278 * * *$ & -0.0018 & $0.0394 * * *$ \\
\hline & $(-0.290)$ & (7.763) & (1.283) & $(5.478)$ & $(-0.274)$ & $(6.497)$ \\
\hline \multirow[t]{2}{*}{ IID } & $0.0907 * * *$ & $0.1077 * * *$ & $0.0904 * * *$ & $0.1348 * * *$ & $0.0918 * * *$ & $0.1251 * * *$ \\
\hline & $(9.658)$ & $(28.369)$ & $(16.889)$ & $(23.348)$ & (10.887) & (18.703) \\
\hline \multirow[t]{2}{*}{ LEV } & $-0.1653 * *$ & $-0.1365 * *$ & -0.1038 & 0.0213 & -0.0050 & 0.0919 \\
\hline & $(-2.416)$ & $(-2.209)$ & $(-1.554)$ & $(0.407)$ & $(-0.062)$ & $(1.221)$ \\
\hline \multirow[t]{2}{*}{ ROA } & $-0.6539 *$ & 0.1226 & 0.5576 & $-0.8382 * *$ & $1.2200 *$ & -0.5118 \\
\hline & $(-1.915)$ & $(0.262)$ & $(1.253)$ & $(-2.208)$ & (1.932) & $(-1.232)$ \\
\hline \multirow[t]{2}{*}{ MB } & $0.0286^{* * *}$ & 0.0126 & $0.2224 * * *$ & $0.0221 * * *$ & $0.0321 * *$ & $0.0407 * * *$ \\
\hline & $(3.930)$ & $(0.880)$ & $(3.355)$ & $(2.676)$ & (1.979) & (5.149) \\
\hline \multirow[t]{2}{*}{$\mathrm{RD}$} & $1.6910 * * *$ & -0.9671 & $2.2449 * *$ & 0.1815 & 0.0000 & $1.8222 * *$ \\
\hline & $(2.585)$ & $(-0.873)$ & $(2.075)$ & $(0.233)$ & (.) & $(2.162)$ \\
\hline \multirow[t]{2}{*}{$\mathrm{CF}$} & $0.2784 * *$ & $0.9176 * * *$ & $0.4816 * * *$ & $0.4128 * * *$ & $0.5554 * *$ & $0.5477 * * *$ \\
\hline & (1.986) & $(5.701)$ & (2.907) & $(2.950)$ & $(2.440)$ & $(3.021)$ \\
\hline \multirow[t]{2}{*}{ SIZE } & $0.0861 * * *$ & $-0.0352 * * *$ & $0.1498 * * *$ & $0.0791 * * *$ & $0.1805 * * *$ & $0.0714 * * *$ \\
\hline & (4.186) & $(-3.192)$ & $(17.197)$ & (9.088) & $(13.687)$ & $(7.423)$ \\
\hline \multirow[t]{2}{*}{ ALPHA } & $-0.0800 * * *$ & $-0.0893 * *$ & $-0.0983 * * *$ & -0.0646 & -0.0684 & $-0.1058 * *$ \\
\hline & $(-2.604)$ & $(-2.121)$ & $(-3.006)$ & $(-1.559)$ & $(-1.294)$ & $(-2.410)$ \\
\hline \multirow[t]{2}{*}{ RESID } & 0.0111 & 0.0034 & $0.0549 * * *$ & -0.0142 & -0.0021 & 0.0118 \\
\hline & $(0.948)$ & $(0.214)$ & $(4.567)$ & $(-0.970)$ & $(-0.113)$ & $(0.754)$ \\
\hline \multirow[t]{2}{*}{ CONS } & $0.5082 * * *$ & $1.8586 * * *$ & $-0.1719 *$ & $0.7024 * * *$ & 0.0225 & $0.5037 * * *$ \\
\hline & $(4.001)$ & $(15.365)$ & $(-1.662)$ & $(8.089)$ & $(0.181)$ & $(5.352)$ \\
\hline Industry FE & Yes & Yes & Yes & Yes & Yes & Yes \\
\hline Year FE & Yes & Yes & Yes & Yes & Yes & Yes \\
\hline adj. R-sq & 0.179 & 0.177 & 0.331 & 0.228 & 0.313 & 0.216 \\
\hline $\mathrm{N}$ & 3251 & 10263 & 6463 & 6614 & 3003 & 4834 \\
\hline
\end{tabular}




\section{Appendix}

Variable Description

\begin{tabular}{|c|c|}
\hline Analyst Following (AF) & $\begin{array}{l}\text { Log of } 1 \text { plus the number of unique analysts issuing forecast in a } \\
\text { month. }\end{array}$ \\
\hline $\begin{array}{l}\text { Retail Information } \\
\text { Demand (RID) }\end{array}$ & $\begin{array}{l}\text { Number of days in a month a ticker has experienced abnormal Google } \\
\text { SVI. Daily abnormal SVI is coded as } 1 \text { if the daily SVI of a ticker is } \\
\text { greater than the } 96 \% \text { of the previous } 30 \text { days' SVIs, other wise } 0 \text {. }\end{array}$ \\
\hline $\begin{array}{l}\text { Abnormal Retail Demand } \\
\text { (ABN_RID) }\end{array}$ & $\begin{array}{l}\text { RID during a month minus the median RID during the previous } 6 \\
\text { months (as in Da, Engelberg, Gao (2011)) }\end{array}$ \\
\hline $\begin{array}{l}\text { Institutional Information } \\
\text { Demand (IID) }\end{array}$ & $\begin{array}{l}\text { Bloomberg assigns a score of } 0,1,2,3 \text { or } 4 \text { to the variable } \\
\text { "News_heat_read_dmax" if the news readership in a day is below } \\
80 \% \text {, between } 80 \% \text { and } 90 \%, 90 \% \text { and } 94 \%, 94 \% \text { and } 96 \% \text {, or greater } \\
\text { than } 96 \% \text { of the previous } 30 \text { days' hourly counts, respectively. } \\
\text { Number of days in a month a ticker has experienced abnormal news } \\
\text { readership on Bloomberg terminals. Daily news readership measure is } \\
\text { coded as } 1 \text { if the Bloomberg's news readership variable } \\
\text { (News_heat_read_dmax) is } 4 \text {, otherwise } 0 \text {. }\end{array}$ \\
\hline $\begin{array}{l}\text { Abnormal Institutional } \\
\text { Information Demand } \\
\text { (ABN_IID) }\end{array}$ & $\begin{array}{l}\text { IID during a month minus the median IID during the previous } 6 \\
\text { months. }\end{array}$ \\
\hline SIZE & Log of market value $[\log ($ mkvaltq $)]$ \\
\hline MB & Market to book ratio [(atq-ceqq+(mkvaltq))/atq] \\
\hline LEV & Total debt scaled by total assets $[(\mathrm{dlcq}+\mathrm{dlttq}) / \mathrm{atq}]$ \\
\hline $\mathrm{ROA}$ & Operating income scaled by total assets. [oibdpq/atq] \\
\hline $\mathrm{RD}$ & Research and Development expenses scaled by total assets [xrdq/atq] \\
\hline $\mathrm{CF}$ & Operating cash flow scaled by total assets. [oancfy/atq] \\
\hline ALPHA & $\begin{array}{l}\text { One factor Jensen alpha using all the daily returns available in a } \\
\text { quarter. }\end{array}$ \\
\hline RESID & Standard deviation of the residuals from the one factor model. \\
\hline
\end{tabular}

